\title{
DRŽAVA I TRŽIŠNE REFORME
}

\section{STATE AND MARKET REFORMS}

\section{Mašan Ercegović}

\author{
Napredak a. d., Apatin, Srbija
}

CMESTE

JEL Category: 011, D47, P21

\begin{abstract}
Apstrakt
Skoro četvrt veka od otpočinjanja tržišnih reformi, tranzicija srpske privrede u savremenu i funkcionalnu tržišnu ekonomiju nije dovršena i mi se iznova bavimo otkrivanjem razloga zbog čega i kako se to desilo i ko je odgovoran. Naime, kao i kod zemalja istočne Evrope $i$ kod nas se radilo o prelasku sa socijalističkog (mada specifičnog) na tržišni način privređivanja. Imajući to u vidu, više je nego jasno da je glavni subjekat, katalizator pa i nosilac celog procesa bila država, što je nesumnjivo stavlja u poziciju, ako ne jedinog a ono najodgovornijeg činioca (subjekta) tog procesa. Upravo zato je država, opredeljujući se za primenu tranzitornog umesto reformskog koncepta u postupku tranzicije, čiji je gotovo isključivi fokus bila privatizacija, najzaslužnija za ovako "dobro" stanje naše ekonomije. Stoga, uspostavljanje razvojnog koncepta privrednog sistema, koji će funkcionisati po principima i postulatima savremene i funkcionalne tržišne ekonomije, a koje zahteva svetsko tržište, je ključni faktor da li ćemo postati savremeno $i$ samoodrživo društvo.
\end{abstract}

Ključne reči: država, transformacija, tržište, reforma, ekonomija

\begin{abstract}
Almost a quarter of a century since the beginning of market reforms, the transition of the Serbian economy into a modern and functional market economy has not been completed and we are re-dealing with the reasons why and how it happened and who is responsible. Namely, like in other countries of Eastern Europe, in our country as well, it was about moving from the socialist (albeit specific) to the market economy. Bearing this in mind, it is more than clear that the main subject, the catalyst and the carrier of the entire process was the state, which unambiguously puts it in place of, if not the only one, then the most responsible factor (subject) for this situation. That is precisely why the state, deciding to implement a transitory rather than a reformatory concept in the transition process, whose almost exclusive focus was privatization, is most deserving for this "good" state of our economy. Therefore, the establishment of the developmental concept of the economic system, which will function according to the principles and postulates of a modern and functional market economy, required by the world market, will be a key factor in becoming a modern and self-sustaining society.
\end{abstract}

Keywords: state, transformation, market, transition, reform, economy

Adresa autora:

Mašan Ercegović

害”masan.ercegovic@yahoo.com

\section{UVOD}

Država, kao najviši oblik organizovanja ljudske zajednice imala je veliku ulogu u razvoju ljudskog 
društva. Njom su se bavile i bave sve društvene nauke formirajući tako niz teorija o njenom nastanku i karakteru. Bez obzira na razne teorije o nastanku države, ona u savremenom društvu predstavlja civilizacijsku tekovinu koja se sa stanovišta potrebe savremenog čoveka predstavlja 'condico sine qua non', njegovog normalnog života.

Određena uloga države u privrednom životu nikada nije dovođena u pitanje. Teoretičari ekonomske misli i državnici - političari oduvek se spore o tome:

1. Kolika uloga države u privredi treba da bude i po obimu i po strukturi;

2. Na koji način država treba da ostvaruje svoju ulogu u privrednom životu?

$\mathrm{U}$ teoriji i praksi ekonomske misli i privrednog života formirala su se različita shvatanja pozicije i uloge države koja bi se mogla grupisati na sledeći način:

a. merkantilistička i fiziokratska shvatanja;

b. shvatanja klasične ekonomske misli;

c. shvatanja u doba liberalnog kapitalizma;

d. period državnog kapitalizma, koji bi se mogao podeliti na period klasičnog državnog kapitalizma i na period operativnog monetarizma - regulatorne reforme (Kay, J., \& Vickers, J., 1988) kojim započinje era neoliberalnog kapitalizma; i

e. socijalistička država.

Naravno, mi se nećemo vraćati u istoriju već ćemo se fokusirati na savremeni period odnosa države i privrede, kako u zemljama razvijene tržišne ekonomije, tako i na odnos države prema privredi zemalja koje su napustile socijalistički privredni sistem. Drugim rečima u fokusu našeg razmatranja biće period tzv. tranzicije i uloga države u odnosu na privredni sistem, kako zemalja razvijene tržišne ekonomije, tako i zemalja koje su napustile socijalizam i vratile se kapitalističkom načinu privređivanja. Dakle, prvi koraci u tranziciji su urađeni u ekonomijama razvijene tržišne privrede koje su se suočile sa određenim disbalansima i neravnotežama poznatim kao stagflacija i rešavana su tzv. „regulatornom reformom" (Friedman, 1970), na principima operativnog monetarizma. Osnovna karakteristika tih promena se ogledala u privatizaciji preduzeća u javnoj svojini i liberalizaciji tj, njihovo prepuštanje slobodnom delovanju tržišta. Kada su u pitanju zemlje koje su napustile socijalistički privredni sistem i vratile se kapitalističkom načinu privređivanja, tu su izazovi, logično bili mnogo veći a nepoznanice prirodno stanje stvari. $U$ tim i takvim uslovima trebalo je formirati teorijske osnove za te privredno sistemske promene. $\mathrm{Na}$ osnovu izbora karaktera tržišne privrede formiraju se, praktično dva teorijska pristupa.

Teorijski osnovi za privredno sistemske promene radi izgradnje „slobodnog tržišta“ (free market) oslanjaju se na neoklasičnu paradigmu, odnosno na individualistički tip državnog intervencionizma (individualistic capitalism) (Yeager, 1972). To su tranzitorne promene.

Teorijski osnovi za privredno sistemske promene radi izgradnje "vođenog tržišta" (governed market), oslanjaju se na postkejnzijansku školu ekonomske misli i protežiraju kolektivistički tip kapitalizma (communitary capitalism). Taj pristup privredno sistemskim promenama se zasniva na postkejnzijanskoj školi ekonomske misli i predstavlja reformske promene (Babic ...).

Izbor između ta dva pristupa - koncepta privredno sistemskih promena u postsocijalističkim zemljama $u$ procesu prelaska sa planske socijalističke privrede na tržišnu privredu, u perspektivi će biti prevashodno determinisan ideološkim predznakom vladajućih garnitura a ne konsenzusom ekonomista.

\section{TRANZICIJA}

Odnos države i ekonomije se posebno aktuelizovao silaskom „realnog socijalizma“ sa istorijske scene i novom ulogom države, koju je trebalo definisati u novim okolnostima tranzicije kompletnog društveno - političkog i ekonomskog sistema zemalja bivšeg socijalističkog bloka.

Uloga države u kapitalističkim zemljama, tj. privredama razvijene tržišne ekonomije je bila evolutivnog karaktera i razvijala se zajedno sa potrebama društva i ekonomije, nekad sa više nekad sa manje snage i uticaja, ali prevashodno determinisana potrebama privrede - ekonomije. Uloga se menjala, ali je uvek odgovarala određenom stepenu tehnološkog razvoja i interesima glavnih ekonomskih subjekata koji su bili nosioci tehnološkog razvoja. Privredni sistem „realnog socijalizma“ je predstavljao distorziju iz navedenog evolutivnog karaktera odnosa države i privrede. Tržišne zakonitosti zamenilo je državno 
centralističko planiranje. Način vraćanja na taj evolutivni put bio je nepoznat. U takvoj situaciji bilo je logično da će najveći uticaj na teoriju i praksu tranzicije imati privredno-ekonomska filozofija dominantna u zemljama razvijene tržišne ekonomije, koja je u posmatranom periodu dominantno bila zasnovana na postulatima neoklasične ekonomske misli. Shodno tome formirani su teorijski temelji tranzicije (Lipton \& Sachs, 1990), koji su se sastojali u sledećem:

1. Uvođenje fundamentalnih tržišnih zakonitosti na sledeći način:

a. Država se odriče centralističkog i direktivnog planiranja proizvodnje, raspodele, razmene $\mathrm{i}$ potrošnje, a preduzeća kao osnovni ekonomski subjekti u skladu sa tržišnim uslovima utvrđuju sve svoje funkcije;

b. Privatizacija državno socijalističke imovine je neophodan uslov koji prati ukidanje centralističkog i direktivnog planiranja od strane države;

c. Liberalizacija cena, spoljne i unutrašnje trgovine.

2. Monetaristička ekonomska misao i učenje predstavlja osnov za vođenje ekonomske politike.

Dakle, država, od subjekta koji u „realnom socijalizmu" predstavlja ekonomski centar zemlje, u novim okolnostima tranzicije a u skladu sa neoklasičnim ekonomskim učenjem svoju ulogu svodi na:

1. ulogu države kao garanta izvršenja ugovora;

2. ulogu države kao zaštitnika privatne svojine $i$ ostatka državne svojine; i

3. ulogu kreatora i realizatora ekonomske politike (Stojanovic, 2000).

Drugim rečima, odrekla se svog autoriteta u privrednom životu zemlje i pre nego sto je stvorila uslove za funkcionisanje tržišne ekonomije u skladu sa bilo kojom privrednom filozofijom.

Shodno napred navedenoj privredno ekonomskoj filozofiji tranzicija u istočnoevropskim zemljama se sprovela u tri faze. Prva faza je bila uspostavljanje stabilne i konvertibilne valute i vođenje čvrste monetarne i fiskalne politike. Druga faza se zasnivala na liberalizaciji cena ,spoljne i unutrašnje trgovine i demonopolizaciji državnog sektora. I na kraju treća i najznačajnija faza je bila faza privatizacije po konceptu tzv. "šok terapije". I upravo ta treća faza, faza privatizacije je bila ključni faktor koji gotovo sve ekonomije bivšeg socijalističkog bloka u prvih deset godina tranzicije doveo u sve moguće ekonomske neravnoteže, počev o rapidnog pada bruto društvenog proizvoda, rasta inflacije, spoljnotrgovinskog deficita do enormnih stopa nezaposlenosti i emigracije najproduktivnijeg dela populacije.

Grupa američkih eksperata, Alis Ameden, Majkl Intriligejtor, Robert Mekintjar i Lens Tejlor, na konferenciji u Moskvi, juna 1995. godine, izneli je tvrdnje da „šok terapija“ predstavlja ideje najprimitivnijeg oblika kapitalizma koji je na zapadu davno prevaziđen $\mathrm{i}$ da je ideološki motivisana. Oni nadalje, smatraju da su bivše socijalističke zemlje trebale da idu putem mešovite privrede kojim su posle drugog svetskog rata išle privrede Nemačke, Italije i Japana (Babić, 1994). Drugim rečima, tranzicija bi bila mnogo uspešnija da je primenjen pristup reformskog a ne tranzitornog koncepta. Tako su neoklasična teorija i njena privredna filozofija dovele ne samo do velikih neravnoteža u privredama posmatranih zemalja, već su ključno doprinele razaranju (koncepta) stare države koje je teklo brže od stvaranja nove (Stojanović, 2000).

\section{TRANZICIJA SRPSKE PRIVREDE}

Tranzicija srpske privrede, posmatrana kroz otpočinjanje sprovođenja odgovarajućih tržišnih reformi, započinje u suštini u periodu 1988-1990. godine, usvajanjem određenih ekonomskih zakona (zakona o preduzećima, zakona o pretvaranju društvene svojine u druge oblike svojine) kao i odgovarajućih ustavnih promena. Tranzicija je proces koji, kako je to već rečeno, podrazumeva sveobuhvatne društvene reforme počev od ustavnih, odnosno institucionalno političkih do privredno sistemskih koje, logično, u svoj fokus imaju pre i iznad svega izgradnju tržišnih institucija. U zavisnosti od prihvaćenog koncepta tranzicije, tranzitorni ili reformski, definiše se i uloga države u procesu tranzicije privrednog sistema.

U Srbiji se država na početku tranzicije opredelila za reformski pristup za razliku od većine ostalih istočnoevropskih zemalja koje su, takođe, ulazile u proces tranzicije. Određeni analitičari smatraju da je do takvog pristupa tranziciji u Srbiji došlo zbog toga što je u Srbiji na prvim višestranačkim izborima pobedila politička stranka leve 
orijentacije, za razliku od pomenutih zemalja, kod kojih je to bilo obrnuto, pobedile su stranke desnih i konzervativnih opredeljenja. No, ratovi, sankcije i na kraju NATO agresija, krajem zadnje decenije dvadesetog veka koji su pogodili Srbiju učinili su da, de facto, intenzivna tranzicija u Srbiji započne tek dvehiljadite godine, nakon poznatih događaja i političkih pro-mena. Imajući to u vidu tranziciju srpske privrede u vremenskom smislu možemo podeliti u osnovi na dva perioda: period 19902000. godina i period 2001-2017. godina, s tim što bismo i ovaj drugi period mogli podeliti u dva, i to period do globalne ekonomske krize (2001-2008) i period posle globalne ekonomske krize (2008-do danas).

Prvi period tranzicije i početak tržišnih reformi, osim što je bio indukovan političkim promena $u$ zemljama socijalističkog bloka, u Srbiji je bio i svesno determinisan od strane same države, imajući u vidu da je ekonomija Jugoslavije, pa time i Srbije već čitavu deceniju bila u stagnaciji što se najbolje vidi iz kretanja bruto društvenog proizvoda (BDP), Tabela 1.

Tabela 1 - Stope rasta društvenog proizvoda

\begin{tabular}{|c|c|c|c|}
\hline & Ukupno privreda & Industrijski sektor & Industrija \\
\hline 1980 & 2,3 & 1,5 & 4,1 \\
\hline 1981 & 1,4 & 1,9 & 4,4 \\
\hline 1982 & 0,5 & 4,5 & 0,0 \\
\hline 1983 & $-1,1$ & $-1,0$ & 1,4 \\
\hline 1984 & 2,0 & 0,0 & 5,1 \\
\hline 1985 & 0,5 & $-5,6$ & 2,7 \\
\hline 1986 & 3,6 & 8,4 & 3,9 \\
\hline 1987 & $-1,1$ & $-4,2$ & 0,7 \\
\hline 1988 & $-1,2$ & $-2,7$ & $-0,1$ \\
\hline Index 1988* & 106,4 & 101,7 & 123,6 \\
\hline Stopa rasta*** & 0,7 & 0,0 & 2,4 \\
\hline \multicolumn{4}{|c|}{ *u milijardama dinara } \\
\hline
\end{tabular}

Izvor: (Miljković, 1989)

Uzroci su bili više nego jasni a ležali su u privrednom sistemu udruženog rada, nesvojinskom karakteru društvene svojine i samoupravnom sporazumevanju i društvenom dogovaranju, kao osnovnim kategorijama koje su determinisali ekonomske odnose između privrednih subjekata. No, kakvi bi stvarni efekti reformskog opredelenja srpske vlasti za tržišne reforme bili ne može se tačno kvantifikovati, a posebno ne realno oceniti, s obzirom da je celu sledeću deceniju (1991-2001) srpska privreda bila izložena apsolutno neregularnim, da ne kažemo nemogućim uslovima poslovanja, iz dobro poznatih razloga. $U$ svakom slučaju, smatram da je opredeljenje za reformski, a ne tranzitorni koncept tranzicije srpske ekonomije bio ispravan, najmanje iz dva razloga: 1) u uslovima, skoro potpuno zatvorene privrede (posebno male) ne postoje osnovni preduslovi za efikasno delovanje tržišnih zakonitosti; i 2) iskustvo istočnoevropskih zemalja sa primenom tranzitornog koncepta tranzicije čija je osnovna karakteristika tzv. "šok terapija“, je pokazalo sve neravnoteže do kojih takav koncept tranzicije dovodi. To se može videti uvidom $u$ njihov privredni rast i stope inflacije $u$ prvih pet godina sprovođenja tranzicije, uz napomenu da nisu bile izložene ničemu sličnome, čemu je bila izložena srpska ekonomija, naprotiv imale su svu podršku razvijenog kapitalističkog sveta. 
Tabela 2 - Kretanje BDP i inflacije u zemljama u tranziciji

\begin{tabular}{|l|c|c|}
\hline & BDP $^{*} \mathbf{1 9 9 1} \mathbf{- 1 9 9 6}$ & Stopa inflacije \\
\hline Zemlje Višegradske grupe & $-0,4$ & 36,6 \\
\hline Balkan (Alb., Bug., Hrv., Mak., Rum.) & $-5,1$ & 281,1 \\
\hline SR Jugoslavija (Srbija i Crna Gora) & $-12,4$ & - \\
\hline Baltik (Tri Z) & $-11,9$ & 186,0 \\
\hline ZND (Zajednica nezavisnih država) & $-10,6$ & 816,0 \\
\hline Od toga Rusija & $-9,1$ & 406,0 \\
\hline
\end{tabular}

* Prosečna stopa rasta

Izvor: Economics in Transition, Eastern Europe and the Former Soviet Union, Regional Overview,

Naravno, ovo je pratila i jako visoka nezaposlenost, niske prosečne zarade koje po kriterijumu kupovne moći iskazuju još nižu vrednost, i što je posebno nepovoljno i istovremeno indikativno, dolazi do rapidnog rasta spoljnotrgovinskog deficita, rasta spoljnog duga i skoro u potpunosti korišćenja deviznih priliva za servisiranje spoljnog duga. Ovaj aspekt tranzicije istočnoevropskih zemalja (visoki spoljni dug) ni do danas nije adekvatno rešen. Sve ovo, logično, ne bi bilo neophodno navoditi, da po mom mišljenju nije trebalo da bude jedno ozbiljno iskustvo za kreatore naše tranzicije, $s$ obzirom da smo $u$ tranziciju sa sveobuhvatnim tržišnim reformama krenuli sa odloženim vremenskim gepom iz, da ponovim, poznatih razloga. Tačno je da je trend svih ekonomskih pokazatelja u tom prvom periodu tranzicije (1990-2000) nepovoljan i negativan, počev od enormnog pada BDP od 53\%, latentne nezaposlenosti zbog vođenja dela socijalne politike preko privrednih (društvenih) preduzeća, obezvređivanja kapitala (osnovnih sredstava) kroz smanjenje amortizacije i ulaganja, i sl., ali je istovremeno održana supstanca od koje se moglo krenuti $u$ jednu ozbiljnu tranziciju po reformskorazvojnom konceptu. Nesporno je, takođe, da je prvi period naše tranzicije vezan za devedesete godine u pogledu ključnih kategorija tržišne ekonomije liberalizacije i privatizacije, kao osnovnih postulata liberalnog tržišnog kapitalizma bio restriktivan, $s$ obzirom na date okolnosti (ratovi, sankcije, bombardovanje) u kojem je privreda funkcionisala, što istovremeno objašnjava (a nesprovođenje tranzitornog koncepta tranzicije po principima tržišnog fundamentalizma koji od početka tranzicije zagovaraju zastupnici neoliberalnog kapitalizma) i pad svih ekonomskih pokazatelja. Ali, nesporno je i da su određene tržišne reforme bile reformskog karaktera, kao uspostavljanje tržišta kapitala, donošenje novog zakona o privatizaciji društvenih preduzeća 1997. godine, nazvan Zakon o svojinskoj transformaciji. Ovaj zakon donosi nekoliko prednosti, prvo, njime je omogućeno da većinski deo društvenog kapitala može svojinski da se u obliku akcija prenese na zaposlene i građane. Druga prednost je bila u tome što nije došlo do brze koncetracije vlasništva, i konačno, treća prednost je bila $u$ tome što je podsticao akcionare da ostvaruju profit i štite svoje vlasničke interese, čime je pokazao svoj reformski i svoj razvojni aspekt. Sve to zbog uslova u kojima se dešavalo nije moglo da da značajnije rezultate $u$ pogledu tržišne transformacije srpske privrede.

Zato se drugi period tranzicije (2001-2017) započet nakon petooktobarskih promena, očekivao sa velikim nadama u celom društvu a posebno u privredi. Dakle, drugi period naše tranzicije ili bolje rečeno period direktnog uvođenja principa i postulata tržišne ekonomije u našu privredu otpočinje u momentu kada su već poznati rezultati primene tranzitornog koncepta tranzicije istočnoevropskih zemalja zasnovanog na šok - terapiji, i bilo je za očekivati da će se to već postojeće iskustvo tih tranzicionih privreda kritički analizirati i kreirati sveobuhvatni koncept reformi koji će nastojati da bar umanji ako već ne može da eliminiše sve anomalije takvog koncepta i koji će biti primeren stanju i potrebama naše privrede. Zato, da bismo najbolje sagledali koliko je bio kvalitetan vladajući koncept tranzicije po kojem su srpska ekonomija i privreda transformisani u tržišnu, odnosno u kapitalističku privredu, analizu ćemo započeti od kraja tj. od analize stanja srpske privrede i ekonomije na kraju 
drugog dela tranzicionog perioda koji se odvijao nakon nailaska globalne ekonomske krize, preciznije perioda od 2008-2017 godine, koji je, navodno, nastao kao posledica globalne ekonomske krize, a ne kao posledica pogrešnog izbora tranzicionog koncepta. Ovo i iz razloga što postoje mišljenja ekonomista, zastupnika fundamentalnih tržišnih reformi i tranzitornog koncepta tranzicije, da je, upravo taj prvi deo drugog perioda, kako ga nazivaju direktne stvarne tranzicije (2001-2008) godine, ujedno i jedini period uspešnog funkcionisanja srpske privrede u novijoj istoriji srpske privrede i da nije prekinut globalnom ekonomskom krizom izveo bi srpsku ekonomiju u savremene razvijene privrede tržišnog tipa. Sagledavajući aktuelno stanje srpske ekonomije i razorne posledice globalne ekonomske krize na našu ekonomiju, smatram da ključni razlog leži prevashodno u pogrešnom izboru tranzicionog koncepta naše ekonomije $i$ privrede i njihovoj nepripremljenosti za ekonomsku krizu i regionalnog karaktera a kamoli globalnu ekonomsku krizu, a ne u samom uticaju i posledicama same krize. Da bi smo bolje razumeli aktuelno stanje naše ekonomije tj. makroekonomskih pokazatelja (BDP, BDP per capita, zaposlenost, stanje javnog i ukupnog duga, stanje spoljnotrgovinskog i platnog bilansa, itd.), prvo ćemo prikazati stanje naše privrede kroz prikaz bilansa uspeha u periodu 1994 - 2015. godina, kako bi se stekla realna slika o tome gde smo danas i sa kakvim performansama naša privrede ulazi u budućnost.

Tabela 3 - Ostvareni neto poslovni rezultati u proteklih 21 godinu

Finansijski efekti srpske privrede preuzeti iz bilansa uspeha*

\begin{tabular}{|c|c|c|c|c|c|c|}
\hline Godina & $\begin{array}{c}\text { Neto } \\
\text { dobitak }\end{array}$ & $\begin{array}{c}\text { Neto } \\
\text { gubitak }\end{array}$ & $\begin{array}{c}\text { Godišnji } \\
\text { neto } \\
\text { efekat }\end{array}$ & $\begin{array}{c}\text { Kumulativni } \\
\text { dobitak }\end{array}$ & $\begin{array}{c}\text { Kumulativni } \\
\text { gubitak }\end{array}$ & $\begin{array}{c}\text { Kumulativni } \\
\text { neto efekat }\end{array}$ \\
\hline 1994 & 668.440 & 3.322 .597 & -2.654 .158 & 668.440 & 3.322 .597 & -2.654 .158 \\
\hline 1995 & 702.683 & 5.107 .919 & -4.405 .236 & 1.371 .123 & 8.430 .516 & -7.059 .394 \\
\hline 1996 & 913.775 & 3.222 .139 & -2.308 .364 & 2.284 .898 & 11.652 .655 & -9.367 .758 \\
\hline 1997 & 1.074 .444 & 3.621 .240 & -2.546 .795 & 3.359 .342 & 15.273 .895 & -11.914 .553 \\
\hline 1998 & 809.250 & 3.785 .866 & -2.976 .616 & 4.168 .592 & 19.059 .761 & -14.891 .169 \\
\hline 1999 & 526.873 & 1.753 .017 & -1.226 .144 & 4.695 .465 & 20.812 .778 & -16.117 .313 \\
\hline 2000 & 374.196 & 7.368 .418 & -6.994 .221 & 5.069 .661 & 28.181 .196 & -23.111 .534 \\
\hline 2001 & 547.618 & 2.023 .007 & -1.475 .388 & 5.617 .279 & 30.204 .203 & -24.586 .922 \\
\hline 2002 & 1.120 .025 & 1.907 .766 & -787.741 & 6.737 .304 & 32.111 .969 & -25.374 .663 \\
\hline 2003 & 1.588 .935 & 2.890 .343 & -1.301 .409 & 8.326 .239 & 35.002 .312 & -26.676 .072 \\
\hline 2004 & 2.372 .506 & 3.647 .239 & -1.274 .732 & 10.698 .745 & 38.649 .551 & -27.950 .804 \\
\hline 2005 & 3.205 .781 & 3.804 .924 & -599.143 & 13.904 .526 & 42.454 .475 & -28.549 .947 \\
\hline 2006 & 5.021 .785 & 3.121 .002 & 1.900 .782 & 18.926 .311 & 45.575 .477 & -26.649 .165 \\
\hline 2007 & 6.448 .659 & 5.398 .352 & 1.050 .307 & 25.374 .970 & 50.973 .829 & -25.598 .858 \\
\hline 2008 & 5.904 .560 & 6.636 .607 & -732.047 & 31.279 .530 & 57.610 .436 & -26.330 .905 \\
\hline 2009 & 4.548 .096 & 6.113 .052 & -1.564 .956 & 35.827 .626 & 63.723 .488 & -27.895 .861 \\
\hline 2010 & 4.382 .104 & 5.623 .822 & -1.241 .718 & 40.209 .730 & 69.347 .310 & -29.137 .579 \\
\hline 2011 & 6.611 .548 & 5.388 .356 & 1.223 .192 & 46.821 .278 & 74.735 .666 & -27.914 .387 \\
\hline 2012 & 5.072 .941 & 5.809 .843 & -736.902 & 51.894 .219 & 80.545 .509 & -28.651 .289 \\
\hline 2013 & 5.341 .899 & 5.618 .771 & -276.872 & 57.236 .118 & 86.164 .280 & -28.928 .161 \\
\hline 2014 & 4.715 .184 & 6.258 .475 & -1.543 .291 & 61.951 .302 & 92.422 .755 & -30.471 .452 \\
\hline 2015 & 4.288 .241 & 3.011 .330 & 1.276 .911 & 66.239 .543 & 95.434 .085 & -29.194 .541 \\
\hline
\end{tabular}

Napomena: Podaci su dati u USD prema vrednosti na dan 31.12.2015. godine. Podaci za ovu tabelu i za sve tabele koje crpe podatke iz bilansa uspeha uzeti su iz originalnih bilansa koje je sačinjavala Služba društvenog knjigovodstva Jugoslavije i Srbije i APR za odgovarajuću kalendarsku godinu.

Da bismo bolje razumeli podatke koji su dobijeni ovom tabelom, tabelarno ćemo prikazati i sledeće podatke-pokazatelje: Neto dugove privrede Republike Srbije; Povećanje neto dugova po godinama 1994-2015; Pokriće stalne imovine sopstvenim kapitalom; 
Tabela 4 - Neto dugovi privrede Republike Srbije

\begin{tabular}{|c|c|c|c|}
\hline Godina & $\begin{array}{l}\text { Potraživanja u aktivi } \\
\text { na početku godine }\end{array}$ & Dugovi u pasivi & Neto dugovi privrede \\
\hline 1991 & 5.735 .017 & 13.035 .464 & 7.300 .447 \\
\hline 1992 & 15.927 .467 & 36.277 .768 & 20.350 .301 \\
\hline 1993 & \multicolumn{3}{|c|}{ Nisu raspoloživi podaci } \\
\hline 1994 & 11.240 .860 & 23.059 .692 & 11.818 .832 \\
\hline 1995 & 14.359 .471 & 32.771 .921 & 18.412 .450 \\
\hline 1996 & 14.039 .549 & 33.345 .104 & 19.305 .555 \\
\hline 1997 & 14.977 .716 & 34.533 .611 & 19.555 .895 \\
\hline 1998 & 14.288 .831 & 34.013 .999 & 19.725 .168 \\
\hline 1999 & 8.637 .524 & 20.486 .339 & 11.848 .815 \\
\hline 2000 & 10.480 .689 & 25.958 .949 & 15.478 .260 \\
\hline 2001 & 11.339 .606 & 27.736 .144 & 16.396 .538 \\
\hline 2002 & 12.767 .408 & 29.319 .363 & 16.551 .955 \\
\hline 2003 & 16.950 .808 & 38.496 .848 & 21.546 .040 \\
\hline 2004 & 20.756 .006 & 46.910 .264 & 26.154 .258 \\
\hline 2005 & 21.118 .126 & 48.438 .755 & 27.320 .629 \\
\hline 2006 & 25.506 .679 & 54.332 .211 & 28.825 .532 \\
\hline 2007 & 34.074 .498 & 76.086 .827 & 42.012 .329 \\
\hline 2008 & 43.332 .097 & 96.943 .494 & 53.611 .397 \\
\hline 2009 & 39.380 .019 & 88.082 .714 & 48.702 .695 \\
\hline 2010 & 38.571 .316 & 84.677 .863 & 46.106 .547 \\
\hline 2011 & 42.662 .874 & 95.681 .115 & 53.018 .241 \\
\hline 2012 & 39.780 .218 & 86.753 .424 & 46.973.206 \\
\hline 2013 & 41.881 .236 & 91.761 .654 & 49.880 .418 \\
\hline 2014 & 38.146 .753 & 91.078 .875 & 52.932 .122 \\
\hline 2015 & 32.405 .075 & 74.781 .995 & 42.376 .920 \\
\hline
\end{tabular}

Napomena: Stanje na dan 31.12.1994. godine predstavlja kumulativno nasleđe iz prošlosti i obuhvata zaduženje u kalendarskoj 2004. Godini, kada je neto dug privrede Republike Srbije (bez Kosova) iznosio 11.818.832.000 US dolara, po kursu 31.12.2015.

Tabela 5 - Povećanje neto dugova privrede po godinama i stanje na poslednji dan tekuće godine

\begin{tabular}{|c|c|c|c|c|}
\hline Godina & $\begin{array}{c}\text { Neto } \\
\text { dugovi privrede na } \\
\text { početku godine }\end{array}$ & $\begin{array}{c}\text { Povećanje u } \\
\text { toku godine }\end{array}$ & $\begin{array}{c}\text { Kumulativno } \\
\text { povećanje }\end{array}$ & $\begin{array}{c}\text { Stanje neto dugova } \\
\text { privrede poslednji } \\
\text { dan u godini }\end{array}$ \\
\hline 1995 & 11.818 .832 & 6.593 .618 & 6.593 .618 & 18.412 .450 \\
\hline 1996 & 18.412 .450 & 893.105 & 7.486 .723 & 19.305 .555 \\
\hline 1997 & 19.305 .555 & 19.305 .555 & 250.340 & 7.737 .063 \\
\hline 1998 & 19.555 .895 & 169.273 & 7.906 .336 & 19.725 .168 \\
\hline 1999 & 19.725 .168 & -7.876 .353 & 29.983 & 11.848 .815 \\
\hline 2000 & 11.848 .815 & 3.629 .445 & 3.659 .428 & 15.478 .260 \\
\hline 2001 & 15.478 .260 & 918.278 & 4.577 .706 & 16.396 .538 \\
\hline 2002 & 16.396 .538 & 155.419 & 4.733 .125 & 16.551 .957 \\
\hline 2003 & 16.551 .957 & 4.994 .084 & 9.727 .209 & 21.546 .041 \\
\hline 2004 & 21.546 .041 & 4.608 .217 & 14.335 .426 & 26.154 .258 \\
\hline 2005 & 26.154 .258 & 1.166 .371 & 15.501 .797 & 27.320 .629 \\
\hline 2006 & 27.320 .629 & 1.504 .903 & 17.006 .700 & 28.825 .532 \\
\hline 2007 & 28.825 .532 & 13.186 .797 & 30.193 .497 & 42.012 .329 \\
\hline
\end{tabular}




\begin{tabular}{|c|c|c|c|c|}
\hline Godina & $\begin{array}{c}\text { Neto } \\
\text { dugovi privrede na } \\
\text { početku godine }\end{array}$ & $\begin{array}{c}\text { Povećanje u } \\
\text { toku godine }\end{array}$ & $\begin{array}{c}\text { Kumulativno } \\
\text { povećanje }\end{array}$ & $\begin{array}{c}\text { Stanje neto dugova } \\
\text { privrede poslednji } \\
\text { dan u godini }\end{array}$ \\
\hline 2008 & 42.012 .329 & 11.599 .069 & 41.792 .566 & 53.611 .398 \\
\hline 2009 & 53.611 .398 & -4.908 .703 & 36.883 .863 & 48.702 .695 \\
\hline 2010 & 48.702 .695 & -2.596 .147 & 34.287 .716 & 46.106 .548 \\
\hline 2011 & 46.106 .548 & 6.911 .695 & 41.199 .411 & 53.018 .243 \\
\hline 2012 & 53.018 .243 & -6.045 .036 & 35.154 .375 & 46.973 .207 \\
\hline 2013 & 46.973 .207 & 2.907 .212 & 38.061 .587 & 49.880 .419 \\
\hline 2014 & 49.880 .419 & 3.051 .705 & 41.113 .292 & 52.932 .124 \\
\hline 2015 & 52.932 .124 & -10.555 .202 & 30.558 .090 & 42.376 .922 \\
\hline 2016 & 42.376 .922 & & & \\
\hline
\end{tabular}

Tabela 6 - Pokriće stalne imovine sopstvenim kapitalom (Slović, \& Slović, 2017)

\begin{tabular}{|c|c|c|c|c|c|}
\hline Godina & Stalna imovina & Kapital & $\begin{array}{c}\text { Stalna imovina- } \\
\text { kapital }\end{array}$ & $\begin{array}{l}\text { \% pokrića } \\
\text { stalne imovine } \\
\text { sopstvenim } \\
\text { izvorima }\end{array}$ & $\begin{array}{c}\text { \% pokrića } \\
\text { stalne } \\
\text { imovine iz } \\
\text { dugova }\end{array}$ \\
\hline 1991 & 16.880 .594 & 14.906 .180 & 1.974 .414 & $88,30 \%$ & $11,70 \%$ \\
\hline 1992 & 81.610 .204 & 74.431 .646 & 7.178 .558 & $91,20 \%$ & $8,80 \%$ \\
\hline 1993 & \multicolumn{5}{|c|}{ Nisu raspoloživi podaci } \\
\hline 1994 & 60.079 .764 & 57.491 .336 & 2.588 .428 & $95,69 \%$ & $4,31 \%$ \\
\hline 1995 & 65.710 .079 & 57.923 .085 & 7.786 .994 & $88,15 \%$ & $11,85 \%$ \\
\hline 1996 & 65.651 .250 & 55.239 .040 & 10.412 .210 & $84,14 \%$ & $15,86 \%$ \\
\hline 1997 & 54.241 .568 & 43.454 .202 & 10.787 .366 & $80,11 \%$ & $19,89 \%$ \\
\hline 1998 & 50.736 .748 & 38.963 .228 & 11.773 .520 & $76,79 \%$ & $23,21 \%$ \\
\hline 1999 & 34.763 .839 & 28.831 .566 & 5.932 .273 & $82,94 \%$ & $17,06 \%$ \\
\hline 2000 & 33.841 .799 & 22.960 .456 & 10.881 .343 & $67,85 \%$ & $32,15 \%$ \\
\hline 2001 & 37.052 .056 & 25.835 .052 & 11.217 .004 & $69,73 \%$ & $30,27 \%$ \\
\hline 2002 & 43.060 .652 & 32.424 .204 & 10.636 .448 & $75,30 \%$ & $24,70 \%$ \\
\hline 2003 & 51.445 .879 & 38.044 .374 & 13.401 .505 & $73,95 \%$ & $26,05 \%$ \\
\hline 2004 & 59.527 .714 & 44.202 .975 & 15.324 .739 & $74,26 \%$ & $25,74 \%$ \\
\hline 2005 & 62.444 .356 & 46.262 .664 & 16.181 .692 & $74,09 \%$ & $25,91 \%$ \\
\hline 2006 & 68.774 .728 & 52.918 .115 & 15.856 .613 & $76,94 \%$ & $23,06 \%$ \\
\hline 2007 & 93.083 .091 & 69.534 .581 & 23.548 .510 & $74,70 \%$ & $25,30 \%$ \\
\hline 2008 & 102.662.996 & 71.085 .591 & 31.577 .405 & $69,24 \%$ & $30,76 \%$ \\
\hline 2009 & 88.644 .990 & 57.853 .841 & 30.791 .149 & $65,26 \%$ & $34,74 \%$ \\
\hline 2010 & 77.073 .953 & 47.758 .443 & 29.315 .510 & $61,96 \%$ & $38,04 \%$ \\
\hline 2011 & 98.757 .906 & 64.957 .952 & 33.799 .954 & $65,77 \%$ & $34,23 \%$ \\
\hline 2012 & 82.860 .094 & 53.123 .465 & 29.736 .629 & $64,11 \%$ & $35,89 \%$ \\
\hline 2013 & 87.235 .688 & 54.027 .794 & 33.207 .894 & $61,93 \%$ & $38,07 \%$ \\
\hline 2014 & 84.637 .528 & 48.753 .543 & 35.883 .985 & $57,60 \%$ & $42,40 \%$ \\
\hline 2015 & 69.955 .999 & 41.202 .149 & 28.753 .850 & $58,90 \%$ & $41,10 \%$ \\
\hline
\end{tabular}


Šta se zapaža na prvi pogled kada se analiziraju prikazane tabele i pokazatelji koji se iz njih dobijaju?

- Prvo, da u celom posmatranom periodu privreda Srbije iskazuje pozitivan poslovni rezultat samo u tri godine od posmatranih dvadeset i jedne, i to u 2006 i 2007, i zatim 2015. godine. 2006 i 2007. godina, se poklapaju sa pozitivnom privrednom konjunkturom u celom svetu, ali i što je mnogo važnije sa rasprodajom naših najboljih kompanija stranim kupcima, pa njihovi ekstra prihodi u kombinaciji sa pozitivnim privrednim trendovima kompenzuju loše stanje većine privrednih subjekata. Pozitivan poslovni rezultat privrede u 2015. godini, predstavlja prve direktne pozitivne efekte podsticanja privlačenja stranih direktnih investicija, koji bi pokazali znatno manje pozitivne efekte kada bi se oni umanjili za iznos podsticajnih sredstava koje im je država, što direktno što indirektno (kroz direktne uplate i fiskalna i parafiskalna oslobađanja) uplatila. Posredan, ali uslovno pozitivan uticaj je bilo i znatno smanjenje troškova radne snage kroz smanjenje nadnica kao posledice „stezanja kaiša“ sprovođenjem Programa fiskalne konsolidacije.

Drugo, očigledno je kontinuirano poslovanje sa negativnim finansijskim rezultatom sa akumuliranim gubitkom od cca. 27.5 milijardi dolara, što nedvosmisleno pokazuje da privreda ne uspeva da se konsoliduje ništa bolje ni u periodu krize (2008-2015) nakon sprovedene privatizacije, nego što je to pokazivala pre nje u periodu izolacije i sankcija u periodu (1990-2000). godine, pre njenog sprovođenja

- Treće, jasno je da kontinuirano poslovanje sa negativnim finansijskim rezultatom mora za posledicu da ima i povećanje zaduženosti što se iz priložene tabele i vidi i ono raste sa 11.8 milijardi dolara u 1995. na 42.3 milijarde dolara u 2015. godini, ili za cca trideset milijardi dolara ili za 1.4 milijarde prosečno godišnje. Naravno zaduženost nije sama po sebi negativan pokazatelj, ona je indikativna zbog činjenice što $u$ istom periodu imamo i negativan poslovni, odnosno finansijski rezultat, što znači da privreda svoju egzistenciju ne zasniva na profitu nego na zaduživanju, da nema investicija pa time nema ni razvoja ni povećanja opšteg društvenog bogatstva;
- Četvrto, pokazatelj koji govori koliko je pokriće stalne imovine sopstvenim izvorima-kapitalom vrlo slikovito pokazuje koliko je u posmatranom periodu bio teret finansiranja poslovanja, što je posebno otežavalo poslovanje privrednih subjekata a čemu je nesporno poseban doprinos dala i kreditno-monetarna politika;

- Peto, kontinuirano poslovanje sa gubitkom u dužem vremenskom periodu, u ovom slučaju preko dvadeset godina, jasno implicira da privreda nema snage da investira i da dolazi do zastarelosti opreme - osnovnih sredstava i u tehničkom i u tehnološkom smislu, ili bolje rečeno da osnovni kapital jede samog sebe, što dodatno otežava šanse privrede da bude ravnopravan partner u međunarodnoj podeli rada uključujući i domaće tržište.

Sagledavajući ovakvo stanje privrede, onda nije čudno što ni opšte stanje ekonomije nije znatno bolje, pa imamo situaciju da je BDP Srbije u 2017. godini, tek nešto oko $80 \%$ od BDP-a iz 1989. godine, dok je rast privredne aktivnosti u odnosu na predkriznu 2008. godinu, veći za svega $3.8 \%$, a odnosu na početak „prave" tranzicije 20002001. godinu, kumulativan rast je svega $64,2 \%$. Ipak Program fiskalne konsolidacije zasnovan na neoliberalnom konceptu monetarne ekonomske škole daje određene pozitivne rezultate $u$ makroekonomskom pogledu, što se ogleda pre svega u smanjivanju relativnog učešća javnog duga u BDP na podnošljivih $61,5 \%$, rastu pokrivenosti uvoza izvozom na šta prevashodno utiču strane direktne investicije, i nesporni pad stope nezaposlenosti bez obzira koji se metod obračunavanja primenjivao, što je takođe pozitivna posledica stranih direktnih investicija. Podsticanje i privlačenje stranih direktnih investicija predstavlja jedini aspekt aktuelne ekonomske politike koji pokazuje karakteristike razvojnog koncepta tranzicije, dok su sve ostale mere zasnovane na tranzitornom konceptu i neoliberalnoj ekonomskoj paradigmi, počev od samog Programa fiskalne konsolidacije, Zakona o radnim odnosima, rasprodaji ili davanju u koncesiju svih preduzeća u državnoj svojini, čvrstoj monetarnoj politici i politici kursa. Sve ovo zajedno nas upućuje da uočeni nedostatak razvojnog i reformskog karaktera u oficijelnom konceptu tranzicije koji je na snazi od 2001. godine, predstavlja osnovni razlog ovakvog stanja naše ekonomije i privrede koji nije uspeo pripremiti 
privredu za suočavanje sa ekonomskom krizom. $\mathrm{Da}$ bi se to bolje razumelo potrebno je vratiti se unazad i analizirati upravo prvi period tranzicije od 2001 do 2008. godine, koji se prikazuje kao posebno uspešan.

Drugi period tranzicije srpske ekonomije i privrede započinje 2001. godine, a njen prvi deo se odvija u intervalu od 2001. do 2008-2009. godine, odnosno do pojave globalne ekonomske depresije. Već po prvim ekonomskim merama, uvođenja čvrstog monetarnog ograničenja i liberalizaciji cena i spoljne i unutrašnje trgovine, bilo je jasno da su se aktuelna vlast i kreatori ekonomske politike opredelili za tranzitorni koncept tranzicije naše privrede $u$ tržišnu zasnovanog na neoliberalnoj tržišnoj paradigmi, bez obzira na već postojeće iskustvo istočnoevropskih zemalja. Poseban i dominantan pečat ovom konceptu tranzicije je dao model privatizacije, koji je za razliku od prethodnog u potpunosti ukinuo mogućnost insajderske privatizacije i kompletan proces promene svojinskih odnosa u preduzećima predao u ruke državnoj administraciji, kako u normativnotehničkom tako u potpunosti i u prihodovnom, jer svi novčani prilivi idu državi. Ciljevi privatizacije su definisani u čl.2 Zakona o privatizaciji koji glasi:
„Privatizacija se zasniva na sledećim načelima:

- Stvaranje uslova za razvoj privrede i socijalnu sigurnost

- Obezbeđenje javnosti

- Fleksibilnost

- Formiranje cene prema tržišnim uslovima“.

Ovako postavljen model privatizacije za period 2002-2009. godina dao je sledeće rezultate prema podacima Agencije za privatizaciju:

- Ukupno na prodaju bilo je ponuđeno 3.471 društveno preduzeće

Ukupno je prodato 2505 preduzeća ili 72,17\%

- Privatizacijom je bilo obuhvaćeno 357.584 zaposlenih

- Ukupan prihod države je iznosio 2,9 milijardi evra

- Ugovorene su investicije u iznosu od 1.4 milijarde evra

- Obavezni socijalni programi su ugovoreni na iznos 277 miliona evra

- Zaključno sa februarom mesecom 2010. godine raskinuto je 510 ugovora o privatizaciji ili 20,36\% (www.priv.rs).

Ovako koncipirana privatizacija imala je dominantni uticaj na ekonomsku, socijalnu i razvojnu uspešnost tranzicije srpske privrede čije ćemo karakteristike najbolje sagledati kroz tabelu 7.

Tabela 7 - Komparativni pokazatelji stanja ekonomije Srbije 2000 - 2008. godina

\begin{tabular}{|c|c|c|c|c|c|c|c|c|}
\hline Godine & $\begin{array}{c}\text { Stopa } \\
\text { rasta BDP } \\
\text { u \% }\end{array}$ & $\begin{array}{c}\text { Deficit tek. } \\
\text { rac. \% } \\
\text { BDP }\end{array}$ & $\begin{array}{c}\text { Učešće u \% } \\
\text { spo. duga u } \\
\text { BDP }\end{array}$ & $\begin{array}{c}\text { Učešće } \% \\
\text { SDI u } \\
\text { BDP }\end{array}$ & $\begin{array}{c}\text { Deficit } \\
\text { robne } \\
\text { razmene }\end{array}$ & $\begin{array}{c}\text { Stope } \\
\text { rasta } \\
\text { kursa }\end{array}$ & $\begin{array}{c}\% \text { Prihod } \\
\text { od privat. } \\
\% \text { u BDP }\end{array}$ & $\begin{array}{c}\text { Rast } \\
\text { nezapos. } \\
\text { u \% }\end{array}$ \\
\hline 2000 & 5,3 & $-1,8$ & & 0,6 & & & & 12,1 \\
\hline 2001 & 5,6 & $-7,6$ & 98,44 & 1,44 & 21,88 & & & 12,2 \\
\hline 2002 & 3,9 & $-11,5$ & 67,5 & 3,14 & 23,75 & 3,0 & 1,99 & 13,3 \\
\hline 2003 & 2,4 & $-9,6$ & 62,64 & 6,95 & 23,56 & 11,1 & 4,83 & 14,6 \\
\hline 2004 & 8,3 & $-14,1$ & 54,45 & 4,07 & 30,37 & 15,8 & 0,82 & 18,5 \\
\hline 2005 & 5,6 & $-10,1$ & 64,22 & 6,13 & 23,53 & 8,1 & 1,85 & 20,8 \\
\hline 2006 & 5,2 & $-13,1$ & 63,4 & 14,85 & 22,98 & $-7,6$ & 1,15 & 20,9 \\
\hline 2007 & 6,9 & $-16,2$ & 60,34 & 6,17 & 24,07 & 0,3 & 1,79 & 18,1 \\
\hline 2008 & 5,42 & $-17,4$ & 63,56 & 5,28 & 23,91 & 11,9 & 0,96 & 14 \\
\hline 2009 & $-3,5$ & - & - & - & - & 8,2 & - & - \\
\hline
\end{tabular}

Izvor: Pregled sačinjen na bazi podataka RZS, Statističkog godišnjaka 2009, Agencije za privatizaciju, MMF i (Drašković, 2009)

U posmatranom periodu ekonomsku komponentu tranzicije sagledaćemo kroz analizu sledećih pokazatelja, BDP, Spoljnotrgovinskog bilansa i Spoljnjeg duga (javnog i privatnog). Očigledan je rast BDP-a od 2,68 puta u 2008. u odnosu na
2001. godinu, što je svakako vrlo pozitivan indikator ekonomskih tokova ako je zasnovan na realnim osnovama. U našem slučaju, nažalost on je bio zasnovan pre svega na rastu domaće potrošnje, koja se finansirala prihodima od 
privatizacije i u manjem obimu od stranih direktnih investicija, čvrstoj monetarnoj politici i shodno tome nerealnom kursu i spoljnom zaduživanju. To se jasno vidi iz činjenica da u posmatranom periodu imamo porast spoljnotrgovinskog deficita sa 2,8 milijarde evra u 2001. na 8,2 milijarde evra u 2008. godini. Za tranzicione privrede stanje ekonomije se posebno mora sagledavati sa stanovišta kretanja bilansa tekućih plaćanja sa inostranstvom i njegovim učešćem u BDP-u, kao i stanja spoljnog duga. $U$ posmatranom periodu, deficit tekućeg računa je porastao sa $7,6 \%$ iz 2001. na $17,4 \%$ BDP u 2008. godini. $U$ istom periodu spoljni dug je porastao sa 12,6 milijardi evra na 21,8 milijardi evra. Imajući ovo u vidu, teško da se može konstatovati da BDP, posmatran samostalno, može da se prihvati kao ključni pokazatelj ekonomske uspešnosti jedne ekonomije. Ova konstatacija naročito dobija na težini kada se uzme u obzir činjenica da se spoljni dug iskazuje i da je fiksiran u stranoj valuti (EUR ili USD), dok se BDP dobija na bazi dinarskih vrednosti čija realna vrednost kada se iskazuje $u$ čvrstoj - stranoj valuti značajno zavisi od realnosti kursa domaće valute. Iz tog razloga se mora sa rezervom i uzeti visina iskazanog srpskog BDP.

Razvojni aspekt uspešnosti primenjenog koncepta tranzicija i modela privatizacije najbolje pokazuje sudbina srpske industrije kao ključnog sektora svake ozbiljne ekonomije i privrede.

Tabela 8 - Stope rasta BDP i Industrije u Srbiji u periodu 2001-2009, stalne cene iz 2002.

\begin{tabular}{|l|r|r|r|r|r|r|r|r|}
\hline & $\mathbf{2 0 0 1}$ & $\mathbf{2 0 0 2}$ & $\mathbf{2 0 0 3}$ & $\mathbf{2 0 0 4}$ & $\mathbf{2 0 0 5}$ & $\mathbf{2 0 0 6}$ & $\mathbf{2 0 0 7}$ & $\mathbf{2 0 0 8}$ \\
\hline BDP & 5,1 & 4,5 & 2,4 & 9,2 & 6,5 & 5,2 & 5,9 & 5,4 \\
\hline Industrija & 0,0 & 2,0 & $-3,0$ & 7,2 & $-0,8$ & 4,7 & 3,7 & 1,1 \\
\hline
\end{tabular}

Izvor: Republički zavod za statistiku, godišnjaci i odgovarajuća mesečna saopštenja

Već i sami statistički podaci slikovito svedoče o onome šta je u stvarnosti mogao uočiti svaki ozbiljniji posmatrač, konstantno zaostajanje rasta industrije $u$ odnosu rast BDP što se najbolje vidi iz činjenice da broj radnika $u$ industriji opada sa 1 milion u 1990. godini na 700 hiljada u 2001. i na svega 400 hiljada u 2009. godini. Srbija je deindustrijalizovana, i bez obzira na tehničkotehnološku zastarelost kapaciteta srpske industrije ključni faktor deindustrijalizacije je model privatizacije koji zasnovan na rasprodaji a ne na razvoju, naprosto nije mogao generisati investicije za koje investitor nije imao promptnu nadoknadu uloženih sredstava.

Zaposlenost kao pokazatelj socijalnog aspekta primenjenog koncepta tranzicije, takođe je ključno determinisan modelom privatizacije i ne može se adekvatno sagledati na osnovu podataka oficijelne statistike najmanje iz dva razloga, prvo zbog upitnosti primenjenih metoda obračuna (a i oni iskazuju enormne stope nezaposlenosti koje se u čitavom periodu kreću između 14 i 20-21\%), već i zbog činjenice da se deindustrijalizacijom gube čitave generacije tehnički kvalifikovanih kadrova koji nemaju gde da se zaposle i koje nema ko da zameni ukoliko dođe do promene razvojnog koncepta ekonomije. Dakle kada se sve sublimira primena tranzitornog koncepta tranzicije, zasnovanog na liberalizaciji i privatizaciji kao ključnim kategorijama neoliberalnog tržišnog učenja u periodu (2001 2008) koji se smatra uspešnim sa stanovišta kreatora primenjenog koncepta tranzicije, svoju efikasnost i kvalitet trebao je da ispolji u periodu globalne ekonomske krize što se, nažalost, nije desilo, a što dešavanje sa našom ekonomijom u vreme globalne ekonomske krize (koja kod nas još nije u potpunosti savladana, makar sa stanovišta razvoja) i potvrđuju, jer je država u narednih šest godina da bi održala elementarni red u ekonomiji i državi bila prisiljena da se prosečno zadužuje između 2,1 i 2,5 milijardi evra godišnje, dok je stopa nezaposlenosti enormno rasla, što nisu mogli prikriti nikakvi modeli statističke evidencije.

\section{ZAKLJUČAK}

Odluka državne vlasti posle oktobarskih promena 2000. godine, da se tranzicija srpske ekonomije i privrede, iz socijalističke u tržišnu sprovede po tranzitornom konceptu tranzicije zasnovanom na neoliberalnim tržišnim principima sa liberalizacijom, čvrstom monetarnom politikom i potpunom i brzom privatizacijom, u neposrednoj praksi se pokazao neadekvatnim i neuspešnim. On se pokazao posebno neuspešnim i u ekonomskom i u socijalnom smislu, u dva najvažnija aspekta za zemlje u tranziciji.

Posledice ekonomske neefikasnosti se manifestuju u: promeni strukture privrede gde je 
došlo do rapidnog smanjenja učešća proizvodnog sektora tj, sektora koji proizvodi razmenljiva dobra u stvaranju BDP-a u odnosu na uslužni i tercijalni sektor, rastu spoljne zaduženosti, nedozvoljivo visokom učešću stranih finansijskih i portfolio investicija u srpskoj ekonomiji i neodrživosti strukture izvoza i uvoza.

$U$ socijalnom smislu neefikasnost se pre svega ogleda u visokoj stopi nezaposlenosti, ali i povećanje socijalne nesigurnosti i rast siromaštva nisu ništa manje bitni indikatori.

I na kraju po redosledu ali najvažniji po značaju za budućnost privrede, ukupne ekonomije i društva u celini, razvojni aspekt primenjenog koncepta ekonomskih reformi pokazao je posebnu neefikasnost koja se ogledala u sledećem: deindustrijalizaciji kao najbitnijem sektoru privrede svih razvijenih ekonomija sveta, nedozvoljivo niskom učešću investicija u DBP-u, oslonac na strane direktne investicije sa vrlo visokim državnim podsticajima da bi se obezbedio kakavtakav privredni rast i nadomestila nemoć domaće privrede da investira i smanjila enormna nezaposlenost, i neravnomernom regionalnom razvoju gde je država potpuno arbitrarno preuzela alokativnu funkciju tržišta.

Ekonomija i privreda su još jednom pokazale da su kao najsloženiji organizacioni sistem društva posle države, kompleksniji od svake ekonomske doktrine koja se rigidno sprovodi i da svaka ekonomija ima svoje specifičnosti kojima treba prilagoditi privredno-ekonomske reforme, a posebno mesto i ulogu države. Posle skoro dvadeset godina primene tranzitorni koncept tranzicije i tržišnih reformi ne da nije dao rezultate, već je i ekonomiju i državu bio uveo u jedan vrtlog destabilizacije i neravnoteža koji je u poslednjem času zaustavljen primenom Programa fiskalne konsolidacije koji je posle dve godine uspeo da uspostavi novu relativnu makroekonomsku ravnotežu. Problem se javlja u činjenici da je fiskalna ravnoteža - relativno smanjenje javnog duga i budžetskog deficita - uspostavljena nakon dodatnog spoljnog zaduživanja, kontroverzne politike kursa (rast vrednosti dinara u odnosu na evro i dolar što smo već ranije objasnili) i perioda najjeftinije cene energenata u novijoj istoriji na šta se ne može računati u dužem vremenskom intervalu. Program, koji je za cilj prevashodno imao fiskalnu stabilizaciju i koji je baziran na čvrstom monetarnom ograničenju i rezanju svih javnih izdataka, takođe ne rešava problem nedovoljnih investicija naše privrede i razvojni aspekt pokušava rešiti podsticajima za strane direktne investicije i rasprodajom ostatka državnih preduzeća.

Imajući sve napred navedeno $u$ vidu, mislim da je više nego očigledno, da je prvi neposredni zadatak svih učesnika i kreatora ekonomske politike a države ponajpre, objediniti sve snage na formulisanju novog razvojnog koncepta ekonomske politike koji će podstaći investicione mogućnosti naše privrede i omogućiti veće stope investicija kao osnovnog generatora razvoja privrede. Nije zadatak ovog rada da licitira sa merama koje bi trebalo preduzeti, ali jedno je sigurno, neophodno je napustiti dosadašnji tranzicioni koncept ili ga u bitnim opredelenjima korigovati. Smatramo da je najmanje potrebno:

- napustiti ulogu države definisanu po konceptu neoliberalnog tržišnog fundamentalizma;

- napustiti primenjivanu strategiju dalje rasprodaje državnih, javnih i prirodnih dobara, i ako postoji potreba za privlačenjem privatnih investicija u sektorima privrede gde su ti oblici vlasništva ili interesa prisutni u značajnoj meri, to raditi na principu joint venture ugovora, ugovora o javno-privatnom partnerstvu i slično, kako bi se obezbedio nadzor, najbolji rezultat $\mathrm{i}$ korist $u$ interesu društva kao celine;

prilagoditi mere fiskalne i kreditno-monetarne politike tom zadatku i cilju tj. podsticanju investicione aktivnosti i postizanju viših stopa razvoja, kao jedine garancije stabilizacije privrede i ekonomije;

poseban naglasak dati na razvoj sektora koji proizvodi razmenljiva dobra, posebno industriju i one sektore koji proizvode za izvoz i usmereni su na inostrana tržišta.

\section{CITIRANA DELA}

Avramović, D. (1994). Privreda Jugoslavije u uslovima blokade. Beograd: SANU

Avramović, D. (1994). Tranzicija u Istočnoj Evropi. Beograd: Evropski centar za mir i razvoj

Babić, B.S. (1996). Prelaz u tranziciji. Beograd: Prometej 
Drašković, B. (2009). Kraj privatizacije i posledice po razvoj. Beograd: Institut ekonomskih nauka

Friedman, M. (1970). The Counter - Revolution in Monetary Theory. London: Institute of Economic Affairs

Jovanović, P. (1994). Uloga države u savremenoj privredi - Velika Britanija, SAD i Jugoslavija. Beograd: Ekonomski institut.

Kay, J., \& Vickers, J. (1988). Regulatory Reform in Britain. Economic Policy, 7, 285-343.

Lipton, D., \& Sachs, J. (1990). Creating a market economy in Eastern Europe: The Case of Poland. Brookings Papers on Economic Activity, 21(1), 75-148.

Marsenić, D., Rikalović, G., \& Gavrilović - Jovanović, B. (1996). Ekonomika Jugoslavije. Beograd: Ekonomski Fakultet

Miljković, D. (1989). Jugoslavija 1918 - 1988: statistički godišnjak. Beograd: Savezni zavod za statistiku.

Nikolić, G. (2018, mart 15). Povratak Srba u kapitalizam i „vidljiva ruka politike“. Beograd: Nedeljnik.

RZS. (2008). Dva veka razvoja Srbije, statistički pregled, Beograd: Republički zavod za statistiku.

Slović, D., \& Slović, S. (2017). Spasavanje srpske ekonomije. Beograd: Confineks.

Stanje i struktura javnog duga - decembar 2017. MFRS - Uprava za javni dug

Statistički godišnjaci RZS, Srbije

Stiglic, DŽ. E. (2002). Protivurečnosti globalizacije. Beograd: SBM-x

Stojanović, I. (2000). Država i tržišne reforme. Beograd: Prometej

Yeager, L. (1972). Monetary Policy and Economic Performance : views before and after the freeze, Washington: American Enterprise Institute for Public Policy Research

Zakon o svojinskoj transformaciji; SI. Glasnik RS, br.32/97 i 10/2001.

Datum prve prijave:

13.03.2018

Datum prijema korigovanog članka: $\quad$ 20.07.2018.

Datum prihvatanja članka:

05.09.2018

\section{Kako citirati ovaj rad? / How to cite this article?}

Style - APA Sixth Edition:

Ercegović, M. (2018, 10 15). Država i tržišne reforme. (Z. Čekerevac, Ur.) FBIM Transactions, 6(2), 1931. doi:10.12709/fbim.06.06.02.03

Style - Chicago Sixteenth Edition:

Ercegović, Mašan. 2018. „Država i tržišne reforme.“ Urednik Zoran Čekerevac. FBIM Transactions (MESTE) 6 (2): 19-31. doi:10.12709/fbim.06.06.02.03.

Style - GOST Name Sort:

Ercegović Mašan Država i tržišne reforme [Časopis] // FBIM Transactions / ur. Čekerevac Zoran. Beograd : MESTE, 1510 2018. - 2 : T. 6. - str. 19-31.

Style - Harvard Anglia:

Ercegović, M., 2018. Država i tržišne reforme. FBIM Transactions, 15 10, 6(2), pp. 19-31.

Style - ISO 690 Numerical Reference:

Država i tržišne reforme. Ercegović, Mašan. [ur.] Zoran Čekerevac. 2, Beograd : MESTE, 15102018 , FBIM Transactions, T. 6, str. 19-31. 